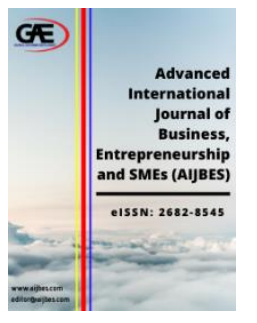

\author{
ADVANCED INTERNATIONAL JOURNAL OF \\ BUSINESS, ENTREPRENEURSHIP AND SMES \\ (AIJBES) \\ www.aijbes.com
}

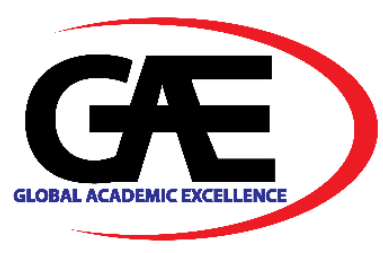

\title{
PROPOSED STRATEGIES FOR PT INDO AIRCRAFT MAINTENANCE RELATED TO ENVIRONMENTAL CHANGES DUE TO THE PANDEMIC
}

\author{
Alfia Kumala Nur Azizah ${ }^{1 *}$, Alibasjah Inggriantara ${ }^{2}$ \\ 1 School of Business Management, Bandung Institute of Technology, Indonesia \\ Email: alfia_azizah@sbm-itb.ac.id \\ 2 School of Business Management, Bandung Institute of Technology, Indonesia \\ Email: alibasjah.i@gmail.com \\ * Corresponding Author
}

\section{Article Info:}

Article history:

Received date:24.02.2021

Revised date: 07.03.2021

Accepted date: 24.03.2021

Published date: 31.03 .2021

\section{To cite this document:}

Azizah, A. K. N., \& Inggriantara, A. (2021). Proposed Strategies for PT Indo Aircraft Manintenance Related to Environmental Changes Due to The Pandemic. Advanced International Journal of Business, Entrepreneurship and SMEs, 3 (7), 135-152.

DOI: $10.35631 /$ AIJBES.370011.

This work is licensed under $\underline{\text { C B BY 4.0 }}$

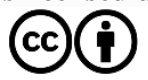

\begin{abstract}
:
Indo Aircraft Maintenance (IAM) is a company in Indonesia occupied in Maintenance, Repair, and Overhaul (MRO) which has the majority of the market share in the domestic area. Previously, in March 2020 large-scale social restrictions (LSSR) has been implemented globally that limits activities affecting the number of airline passengers. In order to recover, a formulation of a new business strategy is required. This research uses a qualitative method by doing a semi-structured interview with the Senior Manager of the Strategy Management division. The Author conducts an environmental analysis with Porter's 5 forces, PESTEL, and VRIO tools, while the strategy formulation was carried out using IFE, EFE, and Internal-External Matrix. The analysis represents, the company is suitable to carry out hold and maintain strategy where market penetration and product development are the alternative strategies. Market penetration is the right choice to create optimum results. The whole business-unit should not only focus on aircraft maintenance but another market segment also. Product development is not the main option that needs to be prioritized since it requires new technology capabilities to a tapped new customer.
\end{abstract}

Keywords:

Business Strategies, LSSR, Market Penetration, MRO Industry, Product Development

\section{Introduction}

The aviation industry includes aspects not only aircraft but also manufacturing, maintenance, airports, and other types of air transportation. Because of its broad reach in helping people to 
Volume 3 Issue 7 (March 2021) PP. 135-152 DOI 10.35631/AIJBES.370011

travel, MRO industry helps boost the economies of countries around the world. Creating more than 50 million jobs, total aviation had generated \$ 2.7 trillion. Assuming as a country, aviation would be in the 20th position in terms of the largest GDP worldwide (IATA, 2018).

Despite playing an important role, global business does not always run smoothly. The industry has been hit by a couple cases, namely when the SARS outbreak hit and the 9/11 incident which forced aviation to stop and resulting decrease every year. Once again, aviation receives an obstacle in 2020 when the Covid-19 pandemic begins to spread from Wuhan, China. Many countries have begun to limit contacts with its neighbouring countries to minimize the spread. In addition, governments have decided to restrict social activities or what are commonly called large-scale social restrictions (LSSR). With the enactment of the new regulations, public transportation enthusiasts including air passengers have dropped dramatically in 2020. It was noted that there was a decrease of 1,865,900 aircraft passengers at Indonesia Main Airports (Central Bureau of Statistics in Indonesia, 2020).

The reduced flight path has resulted in many fleets being rested so that the demand for MRO services is linearly related to the demand for airplane passengers. It is estimated revenue can decrease by $30-50 \%$ since customers such as aircraft companies want to reduce their expenses to the minimum including in terms of MRO expenses (Moody's Investor Service, 2020). Indo Aircraft Maintenance (IAM) is one of the companies affected by the pandemic. IAM is a company specialized in Maintenance, Repair and Overhaul of many aircrafts domestically and globally. IAM is able to carry out aircraft maintenance and repair from line maintenance to overhaul, maintenance and repair of engines and components. Business development continued and IAM began providing Industrial Gas Turbine Engine (IGTE) maintenance services as well as Industrial Generator Overhaul maintenance, which became a new source of revenue.

Since IAM main income is from airlines, the reduce spending from one side will have an impact on the other side, namely MRO industry. Firm revenue decreased by $35 \%$ up until the first semester same period last year and continue to drop to almost $50 \%$ until the third quarter of 2020. The pandemic is increasingly worrying and has an impact on the policies of various countries, causing significant uncertainty for the aviation industry. Currently the MRO market shows an unattractive force, where problems cannot be avoided and must be resolved quickly. Therefore, to be able to solve existing problems the company needs to have the right business strategy and be able to get through the pandemic with satisfactory performance. To be able to produce the desired strategy, the objectives of the study were determined, namely: (1) Identifying the company's environmental factors, (2) Designing a new business strategy that could help the company.

\section{Literature Review}

There are three points will be discussed in Literature Review which are environmental analysis, corporate strategy, and business strategy. Each point, the author will use different tools or framework that has been obtained through reading books or previous research.

\section{Environmental Analysis}

Environmental analysis or scanning is a comprehensive term that includes monitoring, evaluation, and dissemination of information relevant to the development of organizational strategies. Environmental scanning is divided into two, internal and external (Wheelen and Hunger, 2017). The purpose of it was to test empirically the relationships between the environmental scanning activities of upper-level executives and their organizations' strategies, 
Volume 3 Issue 7 (March 2021) PP. 135-152 DOI 10.35631/AIJBES.370011

on the premise that executives would scan to reinforce their organization's particular basis for competing (Hambrick, 1982). According to Morrison's (1992) upon the application of environmental scanning specifically in higher education contexts. Morrison defines several key concepts, including environmental scanning itself, external- and internal-analysis, task-, industry- and macro-environment, also active scanning.

\section{Porter's 5 Forces Tool for External Factors}

Michael Porter's five competitive forces model has been a most influential model within business schools but has perhaps had less appeal to the practicing manager (Grundy, 2006). Michael E. Porter has formulated 5 forces that can affect company's performance. The stronger the five forces, the lower the potential profitability of the industry, making the industry less attractive to competitors. Therefore, the company must be positioned in such a way as to eliminate the limits of its strong forces and take advantage of the weak ones (Rothaermel, 2018). Moreover, in the fight for market share, competition is not manifested only in the other players. Rather, competition in an industry is rooted in its underlying economics, and competitive forces exist that go well beyond the established combatants in a particular industry. (Porter, 1979).

1. Threat of new entrants

Companies need to know the barriers to entry that must fulfilled. Barriers to entry could be in the form of the need to gain economies of scale, the amount of capital requirements, product differentiation, government policies, lack of access to resources, access to distribution channels, and others (Wheelen and Hunger, 2017).

2. Bargaining power of suppliers

The bargaining power of suppliers affects the intensity of competition in an industry, especially when the supplier industry is dominated by a few companies, the product or service made is unique, substitutes are not available at the moment, etc (Wheelen and Hunger, 2017).

3. Bargaining power of buyers

The buyer holds power, if the buyer takes a large part in purchasing the seller's product or service. Buyer power can also increase because the product purchased represents a high percentage of sales from buyers, thus providing an incentive to shop at a lower price (Wheelen and Hunger, 2017).

4. Threat of substitute of products or services

According to Porter, substitutes can limit the potential returns of an industry because substitutes place an upper limit on the price that companies in that industry can charge for profit.

5. Rivalry among existing competitors

Competition among existing competitors illustrates the intensity of the company in an industry where competition occurs for market share and profitability.

\section{PESTEL Tool for External Factors}

External analysis is an assessment activity that is caused due to the changing environment in which the company operates, in order to have to identify potential threats and opportunities (Parrish, 2016). One of the approaches to understanding how external factors affect a company is to consider the source or proximity of the factors in the PESTEL framework. PESTEL framework is a framework that categorizes and analyses a set of important factors, such as political, economic, socio-cultural, technological, ecological, and legal external factors, which may affect a company. These factors can create opportunities and threats for the company. (Rothaermel, 2018). According to Schuetz, in strategic management, strategy analysis includes an analysis of a company's strategic position. In particular, the PESTEL framework serves to 
Volume 3 Issue 7 (March 2021) PP. 135-152 DOI 10.35631/AIJBES.370011

analyze a company's macroenvironment, i.e., the political, economic, social, technological, ecological, and legal factors that influence a company's strategic position.

\section{Resource-Based Approach to VRIO Tool for Internal Factors}

The quantitative VRIO-based framework is a useful tool to assist top management to identify a list of potential competitive advantages of the available sources (Lin, et al, 2012). Resources are an asset of the organization and are a supporting basis organization. Resources are divided into two, namely tangible assets (such as factories, equipment, finance, location, human assets in terms of number of employees, skills and motivation), and the second intangible assets (such as patent and copyright technology, culture, and reputation). Capability refers to a corporation's ability to exploit its resources. Capabilities consist of business processes and activities that manage resources for change input becomes output (Wheelen and Hunger, 2017).

Each resources or capabilities are divided into two: tangible and intangible assets of the company where next will be analysed using VRIO framework. This framework is implied in the resource-based model, identifying certain types of resources as key to superior firm performance. For a resource to be the basis of a competitive advantage, it must be Valuable, Rare, costly to Imitate. And finally, the firm itself must be Organized to capture the value of the resource. According to this model, a firm can gain and sustain a competitive advantage only when it has resources that satisfy all of the VRIO criteria. Keep in mind that resources in the VRIO framework are broadly defined to include any assets as well as any capabilities and competencies that a firm can draw upon when formulating and implementing strategy (Rothaermel, 2018).

\section{Corporate Strategy}

Corporate strategy is an overall plan for a diversified company. Corporate strategy is what makes the corporate whole add up to more than the sum of its business unit parts (Porter, 1987). Corporate strategy concerns questions relating to where to compete in terms of industry, markets, and geography (Rothaermel, 2018).

\section{Strategy Formulation-Analytical Framework}

Strategy formulation usually referred as strategic planning, is relating to the development of the company's mission, goals, strategies and policies. Strategy formulation starts from a situation analysis where the process of finding strategic fit between external opportunities and internal strengths while overcoming external threats and internal weaknesses. (Wheelen and Hunger, 2017)

In formulating strategies at the corporate level (business-unit), the author uses the Strategy Formulation-Analytical Framework by Fred David which was developed in 2007. The frameworks focus on generating and evaluating alternative strategies, as well as selecting strategies to pursue for strategists. There are 3 stages to develop this framework: input, matching, and decision stage.

Generated feasible strategies can lead the company to a better position. Strategists should only consider a few alternatives that can benefit the organization since the implemented strategy opens up unlimited possibilities for action and unlimited ways to implement these actions. Therefore, the most attractive set of alternative strategies that can be managed should be developed, examined, prioritized and selected. (David, 2019) 


\section{Business Strategy}

According to Andrews, corporate strategy determines the businesses in which a company will compete, and business strategy defines the basis of competition for a given business. Business strategy never been used for all occasions. There is a need to continually review strategic objectives because the environment is always changing. Depending on the stance a company adopts, the purpose id strategy is either to make a business fit into its environment or to use the resources of the business to change the rules of the game (Campbell, 2011)

\section{Porter's Generic Strategies}

Michael Porter developed his Generic Strategies in a 1985 paper entitled Competitive Advantage: Creating and Sustaining Superior Performance. Michael Porter proposed three generic competitive strategies for outperforming other organizations in a particular industry: overall cost leadership, differentiation, and focus. These strategies are called generic because they can be pursued by any type or size of business firm, even by not-for-profit organizations. Cost leadership is the ability of a company or a business unit to design, produce, and market a comparable product or service more efficiently than its competitors. Differentiation is the ability of a company to provide unique and superior value to the buyer. This may include areas such as product quality, special features, or after- sale service. Focus is the ability of a company to provide unique and superior value to a particular buyer group, segment of the market line, or geographic market (Wheelen and Hunger, 2017).

\section{Research Methodology}

During this study, author will analyse environmental factors and mapped it into strength, weakness, opportunity, and threat. Next, strategy formulation will be carried out, and author will make a new proposed strategy according to the company's goals and opportunities that can be achieved by the company using strategy-formulation framework by Fred David. When formulating the issues, author analyse both information from company's data, technology used, political issues, and others.

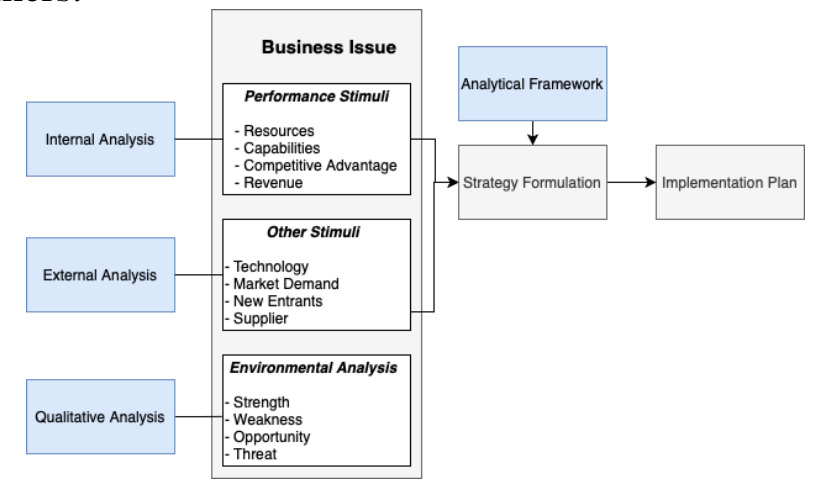

Figure 1: Research Flow Diagram

Source: Author's Analysis, 2020

The research method is a qualitative study using semi-structured interview where scores and ratings are obtained from interviews with company representative. Representative is stakeholders who are tasked with formulating company strategy and hold middle management positions which is the General Manager of Strategy Management. The GM accommodates various suggestions from all departments and devises a strategy for corporate. The value given is the weight and rating for IFE and EFE Matrix. The object of the research is Indo Aircraft Maintenance. Prior to the assessment, an environmental analysis was carried out using several tools. 
In formulating the strategy, there are 3 stages, namely (1) input stage, (2) matching stage, and (3) decision stage. Before proceeding into the framework, author will do an internal and external audit using data that had already been obtained. Each strengths, weaknesses, opportunities, and threats that could disrupt or support the company's performance will be entered into the SWOT table to be calculated using the Internal Factor Evaluation and External Factor Evaluation Matrix.

Author will divide the data into two, namely primary data and secondary data. In the primary data, author obtained data through a discussion that will be conducted between author and PT IAM Senior Manager of Strategy Management. Interview involves unstructured and generally open-ended questions that are few in number and intended to elicit views and opinions from the representative. Apart from interviews, during the process of research, author also collect secondary data by collecting through references from company's reports or other sources. This secondary data is used to support existing problems and other findings apart from primary data.

\section{Data Analysis}

\section{Environmental Analysis}

In order to have a deeper understanding of the environmental analysis that influence IAM, it is divided into two: (1) internal and (2) external factors. The author uses Resource-based approach to VRIO analysis for internal factors which will occupy the strength and weakness in SWOT analysis. For external factors, the author uses PESTEL and Porter's 5 forces analysis where important matter will be put in opportunity and threats in SWOT analysis. The main purpose of a SWOT analysis is to help organizations develop full awareness of all the factors involved in making business decisions. Performing a SWOT analysis is needed before firms commit to any type of action, whether exploring new initiatives, changing internal policies, considering opportunities to rotate or changing plans in the middle of implementation. Through SWOT analysis, company could discover recommendations and strategies, with a focus on leveraging strengths and opportunities to overcome weaknesses and threats (Schooley, 2019).

\section{Porter's 5 Forces}

While observing the industry, companies need to assess the importance of the success of each of the five forces: threat of new entrants, rivalry among existing competitors, threat of substitute products or services, bargaining power of buyers, and bargaining power of suppliers.

\section{Threat of New Entrants}

The arrival of airline fleets and new entrants disrupted the industry and forced businesses to come up with new business models. The airline business has gradually evolved from a focus on in-house fleets to a third-party service offering centred on maintenance services (Frost and Sullivan, 2018). There is also a fleet dynamic that changes from being used for a full-service carrier (FSC) to a low-cost airline (LCC). Many customers also switch to service that offer performance-based service, with the help of OEMs (Airbus and Boeing) that provide pay-peruse and subscription-based-service. In addition, manufacturers are offering customers longterm service contracts to broaden their presence in the MRO market. About $65 \%$ of manufacturing executives believe in their capabilities. However, global disruption from Covid19 and economic downturn is predicted to soften market demand indefinitely (Deloitte, 2020). Therefore, it can be said that the threat of newcomers has a low force. 


\section{Bargaining Power of Suppliers}

Due to the downturn in economic conditions. Airbus, Boeing, and other suppliers or OEM are holding high force as the conditions that are being experienced are also decreasing, making suppliers are forced to manage their cash flow in order to survive. The core of the maintenance industry operations is materials while suppliers nowadays prioritize customers who can provide cash in advanced or clear payment plans. When the customer cannot provide certainty of payment, IAM cannot receive the requested item which hampers operational activities (IAM Representative, 2020). The conclusion is that currently suppliers and vendors are holding high power because their force is important to support MRO operations

\section{Bargaining Power of Buyers}

Buyers at IAM are divided into two, namely affiliated groups and non-affiliated groups. Affiliated groups hold the majority of revenue in the domestic market. Meanwhile in the international market, the majority is held by foreign airlines which is non-group. Before the pandemic occurred, the position of the buyer was already high. For the domestic market, the position of the affiliated group is the parent company. Meanwhile, in the global market, IAM is classified as a small player, so it must meet buyers' demands to gain higher credit. Even though at the moment, customers are demanding a lot of requests, there is no other choice for IAM other than to fulfil those. The changes in the business model caused by industry dynamics, it can be concluded that currently buyers hold high forces.

\section{Threat of Substitute Product or Services}

In MRO business there is a possibility of substitute, since it does not rule out that there will be alternative products or services to replace products and services offered by MRO such as IAM. Perhaps not in the near future, since many companies are currently holding back their capabilities and capacities. While the market demand is unstable until now, the threat to the emergence of substitute products is predicted not to be as much as the usual conditions because industry players are holding back their expenses as efficiently as possible and even cutting some of the facilities and resources. Therefore, the force for substitute can be disclosed as low.

\section{Rivalry Among Existing Competitors}

IAM faces market competition both in Indonesia and abroad. In Indonesia, the enterprise is included in four companies that are consistent in terms of MRO business. Considering other competitors also experienced difficulties, instead of competing, firm tried to enhance consolidation with small businesses and combine forces. There are approximately $74 \mathrm{MRO}$ players in Indonesia. This large number has a market share which is divided into small shares where the largest position is occupied by IAM. The firm has a strong position in Indonesia but overseas the position is reversed. Abroad, it is quite difficult to compete with other competitors which have bigger capabilities. Therefore, the rivalry to competitors is low.

\section{PESTEL Analysis}

PESTEL framework allows company to scan, monitor, and evaluate several changes and trends in firm's macroenvironment. It provides a broad framework in which different macro environmental factors and their impact on performance can be thoroughly examined.

\section{Political Factors}

The Ministry of Industry projects that the potential for the MRO industry in Indonesia will reach USD 2.2 billion in 2025. It is estimated that Indonesia will also be included in the top 10 world aviation markets in 2020, and will continue to rise to the top five in 2034. The aviation 
Volume 3 Issue 7 (March 2021) PP. 135-152 DOI 10.35631/AIJBES.370011

industry absorbs 87.7 million workers worldwide, either directly in the industry or, supporting industries. It is predicted that Indonesia will absorb as many as 12 to 15 thousand MRO experts in the next 15 years. Through adequate facilities and accompanied by infrastructure development in the air transportation sector, it is hoped that it can expand the MRO customer portfolio in Indonesia, improve its reputation in the global market, and most importantly assist the Government in increasing gross domestic product.

\section{Economic Factors}

The buyers or customers faced by the company is mostly the airlines industry. In mid of 2020, Indonesia has received a lockdown status from 59 countries as the case of covid-19 patient is getting worse. The travel restrictions will limit potential customers' opportunities to carry out maintenance in Indonesia. Approaching the end of 2020, many airlines declared bankruptcy making the market size is getting smaller. It is predicted that sustainability airlines will continue to decline until the end of 2020. Firms often have to deal with changes in the price level, which are a direct element of the quantity of money in any economy. There was an increase in the cost of obtaining materials as well as an increase in the volume of subcontract work that had to be done due to the IAM cash flow condition, which was due to the condition of customer liquidity (poor liquidity of the domestic airline industry).

\section{Table 1: Number of Passengers Departing on Domestic Flights at Indonesia Main} Airports

\begin{tabular}{|c|c|}
\hline Year & Number of Passengers \\
\hline 2018 & $44,397,149.00$ \\
\hline 2019 & $36,494,088.00$ \\
\hline
\end{tabular}

Source: Central Bureau of Statistics in Indoneisa, 2020

In addition, the burden for employees has also increased where overall expenses incurred are higher than in 2018. It can be concluded that the increase in resources costs has a direct impact on company performance.

\section{Sociocultural Factors}

Sociocultural factors are not only constantly changing but also different for each group, it is necessary to closely monitor these trends and consider their implications for company strategy. There are predictions that the MRO market for aerospace industry will increase by $5.5 \%$ in Indonesia and $4 \%$ globally. In the short term, orders for new aircraft are likely to decline or experience delays due to the impact of Covid-19, so maintenance of the existing fleet will be even more important. However, for the long term it is predicted that some airlines that are customers will invest in setting up captive or in-house MRO operations. Since it is predicted that the MRO market will continue to thrive and be sustainable in the future, firm needs to pay attention to the trends carried out by other MRO competitors. The Boeing $777 \mathrm{X}$ assembly process is still ongoing and Airbus plans to develop new plane development with zeroemissions, both OEMs need a large amount of resources to help complete development quickly. The need for resources with cheaper wage is greatly needed by manufacturers as the company needs to suppress expenditure as possible on the ongoing project.

\section{Technological Factors}

Current aviation market conditions clarify a new generation of wide-body aircraft will increase penetrations and provide airlines with benefits. After successfully stimulating increased demand for new aircraft, engines, and airframe manufacturers continued to invest in new 
developments. In 2018, the new generation A350-1000 and A3300 neo entered the market and Boeing started introducing the 777x in 2020.

The introduction of a new generation of wide-body aircraft indicates an increase in operating costs and efficiency. The increased efficiency has appropriate economic benefits in terms of fuel combustion, and other weights such as significantly lower maintenance costs. In addition, the more aircraft models that are modified by the aerospace manufacturer, the more complex the operation that will be done by MRO organization will be. The changes of technology drive the changes of business model in airline sector to be more cost-effective to win in the market and keep up with global business dynamics. IAM's capabilities are sufficiently developed to follow the market. However, there are some great capabilities for core operations that are still lacking. This is due to the low demand plus inadequate experience, also there are limited worker skills. For non-core operations there is a work is carried out by subcontracts such as airframe cleaning, component pooling, and other ancillary works. Some ancillary jobs are given to others to reduce the burden of labour costs that must be incurred, but unfortunately subcontracting expenses have become a challenge as income that does not match expectations increases operating expenses.

\section{Ecological Factors}

Ecological factors involve broad environmental issues including sustainable economic growth. The latest issue that IAM has encountered at this time is environmental changes or force majeure caused by the spread of the Covid-19 virus resulting in the company's operational termination as there is no activity from customers and the falling of customer causing management to fail in producing profit.

\section{Legal Factors}

The issue of a new aircraft type could create a new type of regulation. Certification for new capabilities which is always developing is a challenge for the MRO industry as existing knowledge must be updated and training costs money. The industry may hesitate to expand or give up new service opportunities. Without a doubt, to be able to grow, if players has not add new certification, strategy to strengthen their position by increasing their reputation through existing capabilities is another option.

\section{Resource-Based Approach to VRIO Analysis}

Internal analysis is carried out through the VRIO framework to assess the competitive implications of those resources. VRIO is a framework that describes and predicts a firm's competitive advantage. For resources to be competitive advantage, it has to be valuable, rare, costly to imitate, and organized or non-substitutable.

Table 2: VRIO Analysis for Indo Aircraft Maintenance

\begin{tabular}{|l|c|c|c|c|l|}
\hline \multicolumn{1}{|c|}{ Resources } & Valuable & Rare & $\begin{array}{c}\text { Costly to } \\
\text { Imitate }\end{array}$ & Organized & \multicolumn{1}{c|}{$\begin{array}{c}\text { Competitive } \\
\text { Consequences }\end{array}$} \\
\hline Human Resources & $\checkmark$ & $\checkmark$ & & & $\begin{array}{l}\text { Temporary } \\
\text { competitive } \\
\text { advantage }\end{array}$ \\
\hline $\begin{array}{l}\text { Facilities and } \\
\text { Equipment }\end{array}$ & $\checkmark$ & & & & Competitive parity \\
\hline
\end{tabular}




\begin{tabular}{|c|c|c|c|c|c|}
\hline Served Market & $\checkmark$ & $\checkmark$ & $\checkmark$ & & $\begin{array}{l}\text { Temporary } \\
\text { competitive } \\
\text { advantage }\end{array}$ \\
\hline $\begin{array}{l}\text { Collaborations and } \\
\text { Partnerships }\end{array}$ & $\checkmark$ & $\checkmark$ & $\checkmark$ & $\checkmark$ & $\begin{array}{l}\text { Sustainable } \\
\text { competitive } \\
\text { advantage }\end{array}$ \\
\hline $\begin{array}{l}\text { Capability and } \\
\text { Capacity }\end{array}$ & $\checkmark$ & $\checkmark$ & $\checkmark$ & & $\begin{array}{l}\text { Temporary } \\
\text { competitive } \\
\text { advantage }\end{array}$ \\
\hline Market Share & $\checkmark$ & $\checkmark$ & $\checkmark$ & & $\begin{array}{l}\text { Temporary } \\
\text { competitive } \\
\text { advantage }\end{array}$ \\
\hline Reputation & $\checkmark$ & & & & Competitive parity \\
\hline Utility & $\checkmark$ & $\checkmark$ & $\checkmark$ & & $\begin{array}{l}\text { Temporary } \\
\text { competitive } \\
\text { advantage }\end{array}$ \\
\hline Status & $\checkmark$ & $\checkmark$ & $\checkmark$ & & $\begin{array}{l}\text { Temporary } \\
\text { competitive } \\
\text { advantage }\end{array}$ \\
\hline
\end{tabular}

Source: Author's Analysis, 2020

Based on the table above, IAM does not yet have performance implications above average returns and does not have a sustainable competitive advantage.

\section{Research Findings}

\section{SWOT Analysis}

Significant datas from environmental analysis are summarized in the SWOT table which then scored by company's representatives. The strength and weakness are from internal audit and opportunity also threat is from external audit of the company. SWOT analysis will be useful in mapping the Internal-External Matrix which will be carried out in the next chapter.

Table 3: SWOT Analysis for Indo Aircraft Maintenance

\begin{tabular}{|l|c|l|c|}
\hline \multicolumn{1}{|c|}{ Strength } & Symbol & \multicolumn{1}{|c|}{ Weakness } & Symbol \\
\hline Affordable wages & S1 & $\begin{array}{l}\text { Brand's reputation is not strong } \\
\text { overseas }\end{array}$ & W1 \\
\hline $\begin{array}{l}\text { Market power from affiliated } \\
\text { group }\end{array}$ & S2 & $\begin{array}{l}\text { Limited capability has high } \\
\text { market value }\end{array}$ & W2 \\
\hline Privileged company status & S3 & $\begin{array}{l}\text { Quality that have not been } \\
\text { consistent }\end{array}$ & W3 \\
\hline Huge capacity of maintenance & S4 & Too dependent on one market & W4 \\
\hline Cooperation with MRO & S5 & $\begin{array}{l}\text { The high utilization limits } \\
\text { development }\end{array}$ & W5 \\
\hline $\begin{array}{l}\text { Huge portfolio of aircraft } \\
\text { maintenance }\end{array}$ & S6 & $\begin{array}{l}\text { Several KPI have not been } \\
\text { reached }\end{array}$ & W6 \\
\hline $\begin{array}{l}\text { Domestic market shares almost } \\
50 \%\end{array}$ & S7 & Debt-to-Asset (DAR) increased & W7 \\
\hline The largest narrow-body hangar & S8 & Loss in 2019 & W8 \\
\hline
\end{tabular}


Volume 3 Issue 7 (March 2021) PP. 135-152

DOI 10.35631/AIJBES.370011

\begin{tabular}{|c|c|c|c|}
\hline & & $\begin{array}{l}\text { Average collection period value } \\
\text { is high }\end{array}$ & W9 \\
\hline & & $\begin{array}{l}\text { Limited power by Government } \\
\text { and Parent Company }\end{array}$ & W10 \\
\hline Opportunity & Symbol & Threat & Symbol \\
\hline $\begin{array}{l}\text { MRO is projected to grow after } \\
\text { the global economic slowdown }\end{array}$ & O1 & $\begin{array}{l}\text { Airlines started set up their own } \\
\text { MRO business }\end{array}$ & $\mathrm{T} 1$ \\
\hline $\begin{array}{l}\text { There is potential in the ancillary } \\
\text { business }\end{array}$ & $\mathrm{O} 2$ & $\begin{array}{l}\text { The emergence of global players } \\
\text { in Indonesia }\end{array}$ & $\mathrm{T} 2$ \\
\hline $\begin{array}{l}\text { Ample room to increase service } \\
\text { coverage }\end{array}$ & $\mathrm{O} 3$ & $\begin{array}{l}\text { Regional markets affected by } \\
\text { Covid-19 outbreak }\end{array}$ & $\mathrm{T} 3$ \\
\hline $\begin{array}{l}\text { MRO employment increases } \\
\text { with OEMs }\end{array}$ & $\mathrm{O} 4$ & $\begin{array}{l}\text { Market growth suppressed for } \\
\text { lower costs }\end{array}$ & $\mathrm{T} 4$ \\
\hline $\begin{array}{l}\text { MRO facilities in Indonesia is } \\
\text { still low }\end{array}$ & $\mathrm{O5}$ & $\begin{array}{l}\text { OEM capabilities increased to } \\
\text { hinder MRO growth }\end{array}$ & T5 \\
\hline $\begin{array}{l}\text { MRO in Indonesia is projected to } \\
\text { grow }\end{array}$ & O6 & $\begin{array}{ll}\text { Requirements/regulations } & \text { for } \\
\text { MRO companies } & \end{array}$ & T6 \\
\hline $\begin{array}{l}\text { New generation aircraft will cost } \\
\text { more to service and replace }\end{array}$ & $\mathrm{O} 7$ & $\begin{array}{l}\text { Continuous increase in labour } \\
\text { costs }\end{array}$ & $\mathrm{T} 7$ \\
\hline \multirow[t]{3}{*}{$\begin{array}{l}\text { MRO gets full support from the } \\
\text { government }\end{array}$} & O8 & Reduction flight intensity & $\mathrm{T} 8$ \\
\hline & & $\begin{array}{l}\text { Countries have closed routes } \\
\text { with Indonesia }\end{array}$ & T9 \\
\hline & & $\begin{array}{l}\text { Many airlines have declared } \\
\text { bankruptcy }\end{array}$ & $\mathrm{T} 10$ \\
\hline
\end{tabular}

Source: Author's Analysis, 2020

\section{Strategy Formulation Framework for Corporate Strategy}

\section{Input Stage}

In the first stage in strategy formulation, there are two calculations, namely the calculation of rating and scoring on the Internal Matrix and External Factor Evaluation or commonly known as IFE and EFE Matrix. At the input stage, there needs to be a strategist who assesses the rating and weight given, therefore the assessment is given by the General Manager of PT IAM.

Summary of internal-strategic audits through the Internal Factor Evaluation (IFE) Matrix. IFE matrix will summarize and evaluate the major strengths and weaknesses in the business area. No matter how many internal factors, the resulting total weighted score will lie between 1 to 4 .

Table 4: Internal Factor Evaluation Matrix of Indo Aircraft Maintenance

\begin{tabular}{|l|c|c|c|c|}
\hline \multicolumn{1}{|c|}{ Key Internal Factors } & Symbol & Weight & Rating & $\begin{array}{c}\text { Weighted } \\
\text { Scores } \\
\text { (Weight } x \\
\text { Rating) }\end{array}$ \\
\hline \multicolumn{4}{|c|}{ Strength (S) } \\
\hline Affordable wages & S1 & 0,0385 & 4 & 0,1538 \\
\hline Market power from affiliated group & S2 & 0,0577 & 4 & 0,2308 \\
\hline Privileged company status & S3 & 0,0385 & 3 & 0,1154 \\
\hline
\end{tabular}


Volume 3 Issue 7 (March 2021) PP. 135-152 DOI 10.35631/AIJBES.370011

\begin{tabular}{|c|c|c|c|c|}
\hline Huge capacity of maintenance & S4 & 0,0769 & 4 & 0,3077 \\
\hline Cooperation with MRO & S5 & 0,0577 & 4 & 0,2308 \\
\hline $\begin{array}{l}\text { Huge portfolio of aircraft } \\
\text { maintenance }\end{array}$ & S6 & 0,0385 & 3 & 0,1154 \\
\hline $\begin{array}{l}\text { Domestic market shares almost } \\
50 \%\end{array}$ & S7 & 0,0385 & 4 & 0,1538 \\
\hline The largest narrow-body hangar & S8 & 0,0577 & 4 & 0,2308 \\
\hline \multicolumn{4}{|c|}{ Total Weighted Strength } & 1,5385 \\
\hline \multicolumn{5}{|c|}{ Weakness $(\mathbf{W})$} \\
\hline $\begin{array}{l}\text { Brand's reputation is not strong } \\
\text { overseas }\end{array}$ & W1 & 0,0577 & 1 & 0,05769 \\
\hline $\begin{array}{l}\text { Limited capability has high market } \\
\text { value }\end{array}$ & W2 & 0,0769 & 2 & 0,15385 \\
\hline $\begin{array}{l}\text { Quality that have not been } \\
\text { consistent }\end{array}$ & W3 & 0,0962 & 1 & 0,09615 \\
\hline Too dependent on one market & W4 & 0,0577 & 2 & 0,11538 \\
\hline $\begin{array}{l}\begin{array}{l}\text { The high utilization limits } \\
\text { development }\end{array} \\
\end{array}$ & W5 & 0,0769 & 2 & 0,15385 \\
\hline Several KPI have not been reached & W6 & 0,0577 & 2 & 0,11538 \\
\hline Debt-to-Asset (DAR) increased & W7 & 0,0192 & 1 & 0,01923 \\
\hline Loss in 2019 & W8 & 0,0385 & 2 & 0,07692 \\
\hline $\begin{array}{l}\text { Average collection period value is } \\
\text { high }\end{array}$ & W9 & 0,0577 & 1 & 0,05769 \\
\hline $\begin{array}{l}\text { Limited power by Government and } \\
\text { Parent Company }\end{array}$ & W10 & 0,0577 & 1 & 0,05769 \\
\hline \multicolumn{4}{|c|}{ Total Weighted Weakness } & 0,90385 \\
\hline IFE Matr & $(\mathrm{S}+\mathrm{W})$ & & & 2,4423 \\
\hline
\end{tabular}

Source: Representative of Indo Aircraft Maintenance, 2020

The final result of the calculated weighted score is 2.44 which is less than 2.5. It could mean that internally IAM is in a bad position because it is below average. The total weighted score of the strength and weakness factors contributed 1.54 and 0.9, respectively, although weighted strength was greater than weakness, apparently it was not strong enough to produce the desired output.

Same as IFE Matrix, the External Factor Evaluation (EFE) Matrix allows strategists to conclude and evaluate external conditions related to economic, market, environmental and other conditions. The weight and rating are carried out by GM of PT IAM. The rating can vary from 1 to 4 .

Table 5: External Factor Evaluation Matrix of Indo Aircraft Maintenance

\begin{tabular}{|c|c|c|c|c|}
\hline Key External Factors & Symbol & Weight & Rating & $\begin{array}{l}\text { Weighted Scores } \\
\text { (Weight } \mathrm{x} \\
\text { Rating) }\end{array}$ \\
\hline \multicolumn{5}{|c|}{ Opportunity } \\
\hline $\begin{array}{l}\text { The MRO market is projected to grow } \\
\text { after the global economic slowdown as } \\
\text { there is no threat of substitute }\end{array}$ & $\mathrm{O} 1$ & 0.0357 & 4 & 0.1429 \\
\hline
\end{tabular}


Volume 3 Issue 7 (March 2021) PP. 135-152 DOI 10.35631/AIJBES.370011

\begin{tabular}{|c|c|c|c|c|}
\hline There is potential in the ancillary business & $\mathrm{O} 2$ & 0.0536 & 2 & 0.1607 \\
\hline $\begin{array}{l}\text { Ample room to increase service coverage } \\
\text { for Affiliate Groups }\end{array}$ & $\mathrm{O} 3$ & 0.0714 & 2 & 0.2857 \\
\hline $\begin{array}{l}\text { The probability of MRO employment } \\
\text { increases with OEMs }\end{array}$ & $\mathrm{O} 4$ & 0.0714 & 4 & 0.2857 \\
\hline $\begin{array}{l}\text { MRO facilities in Indonesia whose } \\
\text { utilization is still low }\end{array}$ & $\mathrm{O5}$ & 0.0536 & 3 & 0.1607 \\
\hline $\begin{array}{l}\text { The MRO market in Indonesia is projected } \\
\text { to grow }\end{array}$ & O6 & 0.0357 & 4 & 0.1429 \\
\hline $\begin{array}{l}\text { New generation aircraft equipped with the } \\
\text { latest engine technology will cost more to } \\
\text { service and replace if necessary }\end{array}$ & $\mathrm{O} 7$ & 0.0357 & 1 & 0.1071 \\
\hline $\begin{array}{l}\text { The MRO business gets full support from } \\
\text { the government as it brings profits on } \\
\text { foreign exchange }\end{array}$ & O8 & 0.0536 & 3 & 0.1607 \\
\hline \multicolumn{4}{|c|}{ Total Weighted Opportunity } & 1.1786 \\
\hline \multicolumn{5}{|c|}{ Threat } \\
\hline $\begin{array}{l}\text { The increasing tendency of established } \\
\text { airlines to set up their own MRO business }\end{array}$ & $\mathrm{T} 1$ & 0.0536 & 3 & 0.2143 \\
\hline $\begin{array}{l}\text { The emergence of global MRO players in } \\
\text { Indonesia }\end{array}$ & $\mathrm{T} 2$ & 0.0714 & 2 & 0.2143 \\
\hline $\begin{array}{l}\text { The growth of the domestic and regional } \\
\text { markets has been affected by external } \\
\text { factors, especially with the spread of the } \\
\text { Covid-19 outbreak }\end{array}$ & $\mathrm{T} 3$ & 0.0714 & 4 & 0.2857 \\
\hline $\begin{array}{l}\text { Market growth suppressed by lower } \\
\text { maintenance standards for LCC }\end{array}$ & $\mathrm{T} 4$ & 0.0536 & 1 & 0.1607 \\
\hline $\begin{array}{l}\text { Increased OEM capabilities to hinder } \\
\text { MRO business growth by competing in the } \\
\text { same market }\end{array}$ & $\mathrm{T} 5$ & 0.0714 & 3 & 0.2857 \\
\hline $\begin{array}{l}\text { The more requirements for MRO } \\
\text { companies to be more analytical in order } \\
\text { to be able to compete }\end{array}$ & T6 & 0.0357 & 1 & 0.1071 \\
\hline $\begin{array}{l}\text { Continuous increase in labour costs } \\
\text { resulting in a diminishing advantage of } \\
\text { lower labour costs }\end{array}$ & $\mathrm{T} 7$ & 0.0179 & 2 & 0.0714 \\
\hline $\begin{array}{l}\text { There is a reduction in flight intensity due } \\
\text { to the global economic slowdown }\end{array}$ & $\mathrm{T} 8$ & 0.0893 & 2 & 0.3571 \\
\hline $\begin{array}{l}\text { Many countries have closed their routes } \\
\text { "to" and "from" Indonesia }\end{array}$ & T9 & 0.0714 & 2 & 0.2857 \\
\hline $\begin{array}{l}\text { Many of the airline industries have } \\
\text { declared bankruptcy }\end{array}$ & $\mathrm{T} 10$ & 0.0536 & 4 & 0.2143 \\
\hline \multicolumn{4}{|c|}{ Total Weighted Threat } & 1.4643 \\
\hline EFE Matrix $(\mathrm{O}+$ & & & & 2.6429 \\
\hline
\end{tabular}

Source: Representative of Indo Aircraft Maintenance, 2020

For the EFE Matrix, the calculated weighted score is 2.64, which is more than 2.5. In contrast to the IFE Matrix, the calculation of the EFE Matrix implies that the organization responds to 
Volume 3 Issue 7 (March 2021) PP. 135-152 DOI 10.35631/AIJBES.370011

opportunities and threats from external environments. The company's strategy will be more effective if it is focused on existing opportunities and minimizing possible threats.

\section{Matching Stage}

During the matching stage, the tools used will rely on the information that has been provided from the input stage to align external and internal factors.

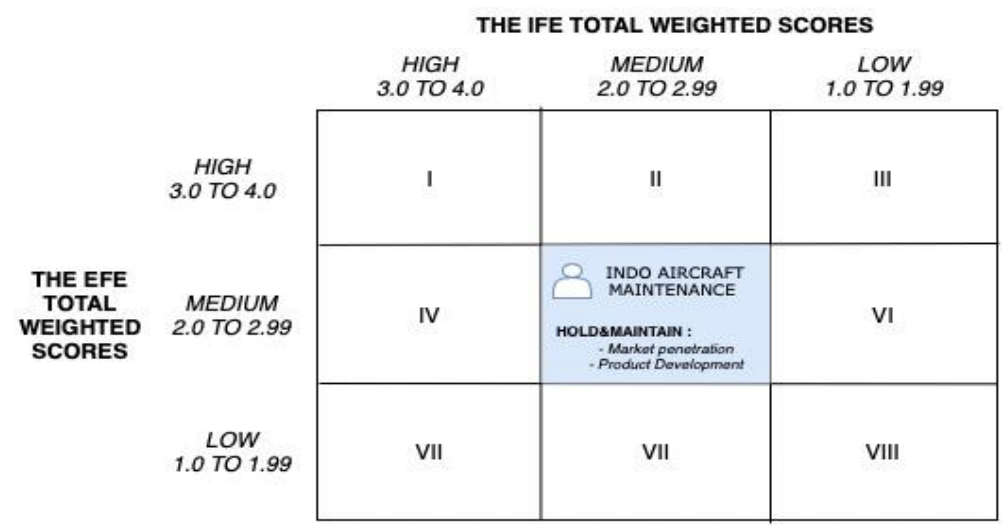

Figure 2: Internal-External Matrix of Indo Aircraft Maintenance

Source: Author's Analysis, 2020

IFE and EFE Matrix values then being lined up into the IE Matrix which shows that the company occupied in cell no. V. The hold and maintain strategy mean an attempt to expand, but not aggressively. Companies can penetrate the market further or develop new products and modify existing products. According to Wheelen and Hunger, on the hold and maintain strategy, the company focuses on market development, a strategy in which a company or business unit captures a larger share of an existing market for current products through market penetration or develops new markets for current products.

\section{Decision Stage}

It is important for a strategist to decide on which strategy firm should pursue so that they can focus on carrying out its activities. The author refers back to the SWOT table to see each of the advantages and disadvantages of the company. The author then classifies them into pros and cons which become the basis for determining the corporate strategy.

Table 6: Pros and Cons of Alternative Strategies

\begin{tabular}{|c|c|c|}
\hline Strategy & Pros & Cons \\
\hline $\begin{array}{c}\text { Market } \\
\text { Penetration }\end{array}$ & 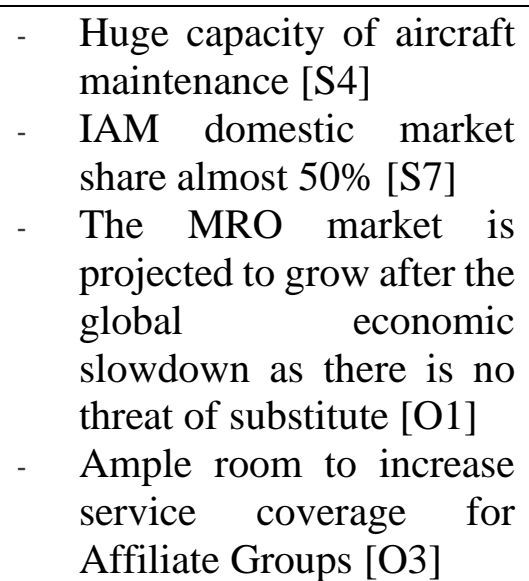 & $\begin{array}{l}\text { - The increasing tendency of } \\
\text { established airlines to set up } \\
\text { their own MRO business [T1] } \\
\text { The emergence of global MRO } \\
\text { players in Indonesia [T2] } \\
\text { - Increased OEM capabilities to } \\
\text { hinder MRO business growth by } \\
\text { competing in the same market } \\
\text { [T5] }\end{array}$ \\
\hline
\end{tabular}


Volume 3 Issue 7 (March 2021) PP. 135-152 DOI 10.35631/AIJBES.370011

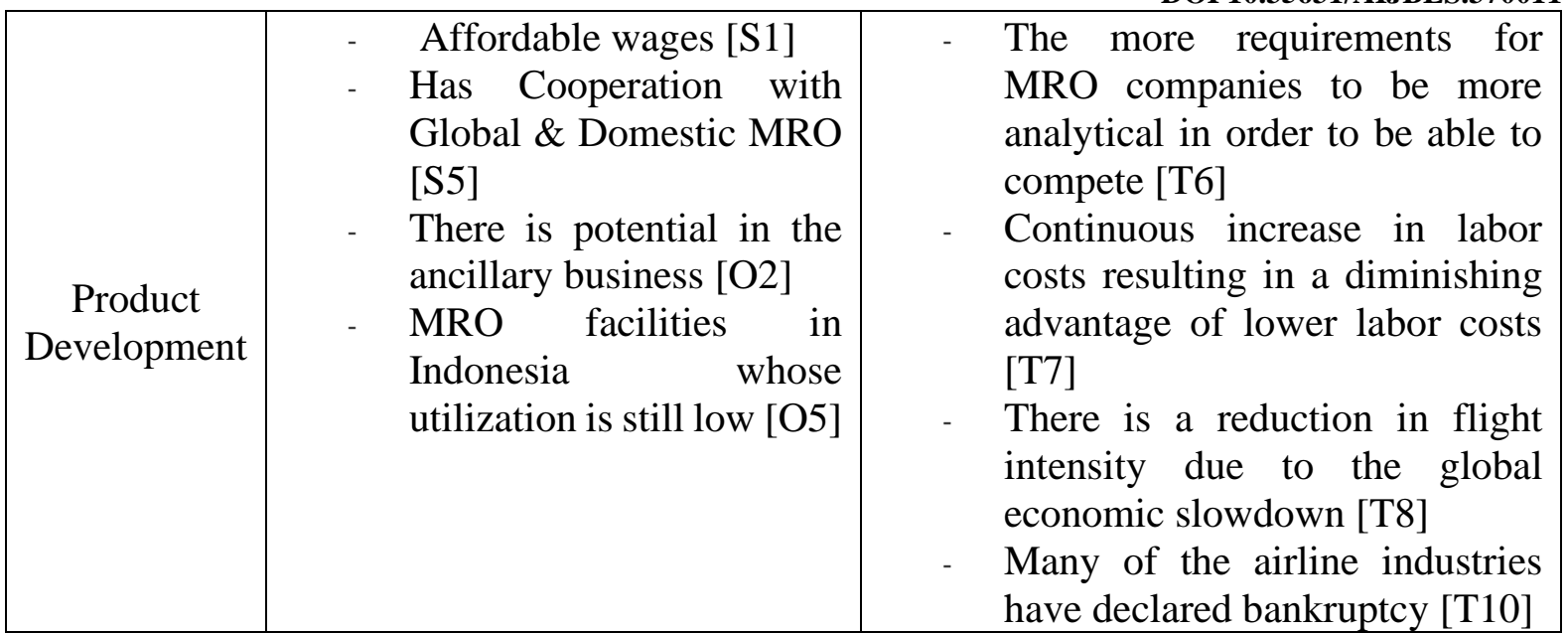

Source: Author's Analysis, 2020

According to the existing financial conditions, IAM should strives to reduce expenses and maximize income. Market penetration can be beneficial as recovery efforts can take place more quickly for Domestic flight services because it is supported by geographical conditions. There are two flight services, namely passenger flights and cargo. Slowly, the affiliated group began to experience an increase in passengers. With the ease of mobility and renewed prevention efforts, the trend of increasing passenger numbers has occurred. For the cargo traffic, the increase occurred due to high public consumption data during the pandemic, which led to an increase in cargo usage. There are several business segments owned by IAM, the commercial aircraft maintenance, specialized aircraft, and the Industrial Gas Turbine Engine Maintenance. As to maximize market penetration, IAM should focus on the untapped market, namely IGTE and specialized aircraft maintenance. Other additions such as private jet and helicopter markets can also be worked on, because the two modes of transportation have the same maintenance concept as the technology capabilities already owned and enthusiasts of both modes are predicted to increase.

Product development is not the main goal that needs to be prioritized since it requires new technology capabilities to tapped new customer behavior. The formulation of new services aims to optimize revenue by spending additional expenses (research trial and error, new capabilities, new marketing effort, etc.), the fact is that the company seeks to minimize capital expenses so that this strategy is not appropriate to implement in the short term.

\section{Generic Strategy for Business Strategy}

COMPETITIVE ADVANTAGE

\begin{tabular}{c|c|c|c|}
\multicolumn{1}{c}{ Lower Cost } & \multicolumn{2}{c}{ Differentiation } \\
\cline { 2 - 3 } Broad Target & COST LEADERSHIP & DIFFERENTIATION & \multirow{2}{*}{$\begin{array}{c}\text { COMPETITIVE } \\
\text { SCOPE }\end{array}$} \\
\cline { 2 - 3 } Narrow Target & COST FOCUS & $\begin{array}{c}\text { DIFFERENTIATION } \\
\text { FOCUS }\end{array}$ \\
\cline { 2 - 3 } & &
\end{tabular}

Figure 3: Porter's Generic Strategy

Source: Adapted from Michael Porter 
Volume 3 Issue 7 (March 2021) PP. 135-152 DOI 10.35631/AIJBES.370011

One of firm's weaknesses is fixating on one capability and market or narrow target. To penetrate the market, the strategy that must be prioritized is cost leadership. The cost-leadership strategy seeks to create similar value for customers by providing products or services at a lower cost, enabling the company to offer lower prices to its customers. Cost leadership creates competitive advantage since offering valuable prices and targeting a wider market. Previously, the IGTE market contributed only $1 \%$ and the rest was owned by the aircraft maintenance market. As an anticipatory action for future unfortunate or unpredicted events, IAM can balance the proportion of share revenue for each business segment. The IGTE market could reach up value of $\$ 12$ million per year and the opportunities for the helicopter and private jet market are expanding. Global chartered air transport market is expected to decline at CAGR of $-2.5 \%$ from 2019 - 2020, but then expected to recover and grow at a CAGR of 7\% in 2021 2023. Thereupon, by pursuing market penetration can bring benefits to the company not only related to revenue gains but also competitive advantage that can help enhance core competencies.

\section{Conclusion}

In conducting the research, there are several limitations that need to be known: (1) the research is focused on designing a strategy for business-unit owned by Indo Aircraft Maintenance at business-unit level, (2) interviews and assessment of strategy formulation were conducted with Senior Manager of Strategic Management due to limited time, and (3) the goal of the research is to solve problems that occur during a pandemic and problems that occurred before the pandemic have no relations to the study. Indo Aircraft Maintenance has a strong position in the domestic area, however to compete in foreign markets, there are still capabilities that are not yet acquired. The arrival of the pandemic has made the activities of customers, namely the airlines industry decreased dramatically where they have a direct relationship which can affect the performance of the MRO industry. During LSSR, many fleets were rested, yet if aircrafts are not operating, still it is necessary to carry out regular maintenance. However, airlines were unable to make profit resulting unable to pay maintenance costs to MRO industry players such as Indo Aircraft Maintenance.

Responding to a dynamic environment, a suitable strategy is needed. The company is faced with two alternative strategies, namely market penetration and product development. Product development requires additional requirements and the opportunity for product enthusiasts does not necessarily exist considering the decrease in flight intensity. There is a possibility that new product development can be done in the medium term but not in the near future because the company wants to reduce expenses. Therefore, the strategy that must be implemented as quickly as possible is market penetration. There are still many market segments that have not been maximized by IAM as evidenced by the largest revenue contributor being dominated by aircraft maintenance, while IAM still has another market segment with the same capability, namely heavy equipment maintenance such as turbines maintenance. Because the purpose of research is to solve problems during a pandemic, for future research, research can be carried out to observes when the pandemic has surcease so a new strategy formulation is needed supported by the dynamics of the industrial environment.

\section{References}

Andrews, K. (1980). The Concept of Corporate Strategy, $2^{\text {nd }}$ edition. Dow-Jones Irwin Campbell, D., Edgar, D., \& Stonehouse, G. (2011). Business strategy: an introduction. Macmillan International Higher Education. 
Volume 3 Issue 7 (March 2021) PP. 135-152 DOI 10.35631/AIJBES.370011

David, F., David, M. E., \& David, F. (2019). Strategic management: A competitive advantage approach; Concepts and cases. Pearson.

Deloitte. (2020, September 29). MRO and Aftermarket services industry insights. Deloitte United

States. https://www2.deloitte.com/us/en/pages/manufacturing/articles/aftermarketservices-mro-industry-insights-beyond-covid-19.html

Deloitte. (2020). The rise of maintenance, repair, and overhaul services. https://www2.deloitte.com/content/dam/Deloitte/us/Documents/manufacturi ng/us-aftermarket-services-ad.pdf

Frost \& Sullivan. (2018). MRO 2025. Frost \& Sullivan Research, Consulting and GIL Events. https://ww3.frost.com/files/8115/4176/6501/MRO_Brochure_1.9.2018_FINA L.pdf

Grundy, T. (2006). Rethinking and reinventing Michael Porter's five forces model. Strategic Change, 15(5), 213-229.

Hambrick, D. C. (1982). Environmental scanning and organizational strategy. Strategic management journal, 3(2), 159-174.

IATA. (2020). Traffic recovery slower than expected. Airlines | IATA's aviation business magazine.

International Air Transport Association. (2018, October 2). Air transport supports 65.5 million jobs and \$2.7 trillion in economic activity. IATA.

Lin, C., Tsai, H. L., Wu, Y. J., \& Kiang, M. (2012). A fuzzy quantitative VRIO-based framework for evaluating organizational activities. Management Decision.

Lineberger, R. Millar, K. \& Wellener, P. (2020). Aftermarket services. Deloitte Insights.

Morrison, J.L. (1992). Environmental scanning. In M.A. Whitley, J.D. Porter, \& R.H. Fenske (Eds)., A primer for institutional researchers (pp. 86-99). Tallahassee, FL: The Association for Institutional Research.

Nugraha, F. A., (2019). Proposed Business Strategy at VJAH Lubricants to Improve the Revenue. Jakarta: Institut Teknologi Bandung

Porter, M. E. (1979, March 1). From Competitive Advantage to Corporate Strategy. Harvard Business Review, 65 (3): 43-59

Porter, M. E. (1979, March 1). How competitive forces shape strategy. Harvard Business Review. https://hbr.org/1979/03/how-competitive-forces-shape-strategy

Rothaermel, F. T. (2018). Strategic Management ( $3^{\text {rd }}$ ed.). McGraw-Hill Education.

Schuetz, C. G., Mair, E., \& Schrefl, M. (2018, October). PESTEL Modeler: Strategy analysis using MetaEdit+, iStar 2.0, and semantic technologies. In 2018 IEEE 22nd International Enterprise Distributed Object Computing Workshop (EDOCW) (pp. 216219). IEEE.

Sivusuo, J., \& Takala, J. (2016). Management changes in MRO business through product lifecycle. Management and Production Engineering Review, 7(3), 87-93.

Ucler, C., \& Gok, O. (2015). Innovating general aviation MRO's through IT: The sky aircraft management system - SAMS. Procedia - Social and Behavioral Sciences, 195, 15031513.

Wheelen, T. L., Hunger, J. D., Hoffman, A. N., \& Bamford, C. E. (2017). Concepts in strategic management and business policy: Globalization, innovation and sustainability. Pearson.

Wyman, O. (2018). MRO survey 2018: Tackling industry disruption. Oliver Wyman - ImpactDriven Strategy Advisors. https://www.oliverwyman.com/ourexpertise/insights/2018/apr/mro-survey-2018.html 
Volume 3 Issue 7 (March 2021) PP. 135-152 DOI 10.35631/AIJBES.370011

Wyman, O. (2020). Aviation Aftermarket and COVID-19. Oliver Wyman - Impact-Driven Strategy

Advisors. https://www.oliverwyman.com/ourexpertise/insights/2020/mar/COVID-19-Impact-On-Commercial-AviationMaintenance.html 